\title{
Effect of Credit Utilization on Output of Rural Youth Rice Farmers in Shiroro Local Government Area, Niger State
}

Ibrahim, M. , Olaleye, R. S. and Umar, I. S.

Department of Agricultural Economics and Extension Technology

Federal University of Technology, Minna Niger State

E-mail Address: gausubrahama@yahoo.com

\begin{abstract}
The study aimed at examining the effect of loan utilization on the output of youth rice farmers in Shiroro Local Government Area of Niger State. The specific objectives are to determine the socio-economic characteristics of the respondents, determine whether there is significant difference in output of the beneficiaries and non beneficiaries and compare the mean output of the youth farmers with and without credits facilities. To achieve the study objectives, 100 respondents from 10 wards was used for data collection. The collected data analyzed using simple descriptive statistics and T-test was used to compare the mean output of credit beneficiaries and non- beneficiaries. The study revealed a significant difference in the mean output of rice farmers who utilize loan $(1,375 \mathrm{~kg} / \mathrm{h})$ with those without credit which was $(275 \mathrm{~kg} / \mathrm{ha})(t-c a l=18.44, p<0.05)$. It was recommended that, the process of acquiring loan should be simplified to encourage and motivate rice growers to acquire loan in order to increase their productivity as well as improve their standard of living. Also farmers on their part should be encouraged to pay back loan obtained.
\end{abstract}

\section{INTRODUCTION}

Agricultural loan refer to temporary transfer of purchasing power from an individual or cooperative society to another (Oyatade, 1981). This facilitate agricultural production efficiency through special function of the skilled farmers, small financial resources such as loans and those who have substantial resources but lack the ability to manage their farms (Oyatode, 1981).

Agricultural productivity is boosted by the small - scale farmers who dwell in the rural areas of the country. The Nigeria rural sector accommodates about $70 \%$ of the nation's population, which makes them play a very vital role in the country's food sector. These small scale farmers operate with little or no capital, as they are low income earners with very low investment, thereby resulting in low efficiency in the utilization of the resources at their disposal, hence affecting their potential to payback. For without credit, new technologies such as use of tractor, herbicide facilities and improved seed varieties may not be adopted. While when these credits have been provided by the financial institutions to the farmers, there is need for an empirical work in the study area to compare the mean output of those farmers with credits and their counterpart in order to generate research information to credit institutions. 
The role credit play in agricultural development has to be widely recognized. The lack of capital or loan results in lack of agricultural development. For instance in most developing countries, a vicious circle of low capital, low income, low saving, low investment and low productivity were found operating and it was perceived that credit was the only input that could break this circle. Awoyemi (1998) discovered that if small scale farmers in the country were to grow and operate on a large scale, there must be an assured supply of credit for short, medium and long terms for without credits, high investment would not be feasible for many farmers.

Rice (Oryza sativa) is the most important cereal in the world with a prime income source for farmers in Nigeria, The fact that rice farmers have mostly small scale farm holdings; domestic production has not increased to meet the economy's demand. As a result of this demand, the Nigeria government has mapped out strategies through policies such as restriction, import tariffs and production incentives as well as subsequent ban in 2006 to boost domestic production of rice. Most rice farmers being small scale farmers have low income and productivity which make it difficult to acquire enough capital to invest in improved agricultural technologies. The financial institutions involved in disbursement of loan have performed far below expectation. Many a times, credits are issued to the wrong individuals while the small scale farmers end up not receiving credit at all. The cost of production is raised, due to high interest rate which deprives most small scale farmers from obtaining credit. In the light of these problem in the study areas, the study specifically seek to:

(i) Determine the socio-economic characteristics of farmers

(ii) Compare the mean output of farmers with credit and those without credits.

(iii) Determine whether there is significant difference in the output of borrowers and nonborrowers.

Theoretical frame work: The impact of loan on rice production in Ondo and Oyo States of Nigeria using simple linear regression model found out that farm size, loan experience were very significant and also the out put of rice was mainly determined by the amount of credit, farm size and experience of rice farmers. Revenue was also determined by the same factors (Fabiyi and Osotimetim, 1984). Similarly a study carried out in Akoko south and Akoko north Local Government area of Ondo State shows that borrowers cultivated large hectare and earned large total and net income than non-borrowers (llebami, 1984).

\section{METHODOLOGY}

The study was conducted in Shiroro Local Government Area of Niger State. The area is located at latitude $8^{\circ}-10^{\circ} \mathrm{N}$ longitude $3^{\circ}-8^{\circ} \mathrm{E}$, It has population of about 114,878 , people (Census, 2006). The vegetation is predominantly shrubs. The inhabitants are mainly Gbagyis and other tribes such as Hausa, Kadara, Koro, Fulani, Nupe, Yoruba and Igbo. The area is characterized by annual rainfall of $1100-1600 \mathrm{~mm}$.

To achieves the objectives of the study, ten villages were purposively selected, namely Gijiwa, Wana, Pina, Rafin-kuta, Gussoro, Erena, Gurmana, Allawa, Kato, Tawo and ten farmers were randomly selected giving a total of 100 farmers. Primary data were collected through the use of structure questionnaires and personal interview. This was complemented with secondary date sourced from text books newspaper and bulletins. The collected data were analyzed with the use of simple descriptive statistics and pair $\mathrm{t}$ - test to enable comparison. 
Journal of Agricultural Extension

Vol. 13 (2) December 2009

\section{RESULTS AND DISCUSSION}

\section{Socio - economic profile of respondents}

Analysis of the socio-economic attributes of the respondents in Table 1 revealed that age is a vital factor in production process. It determines the number of farmers that are among the active farming age. The study revealed that $52 \%$ and $32 \%$ of the borrowers and nonborrowers respectively are within the age range 30-39 years which means that majority of the farmers are within the active age range with a lot of physical strength for farm work if complemented with the necessary incentives in form of credit.

Adegeye Ditto (1985) observed that there is a positive relationship between age and credit. The fact being that the older the farmer, the greater his awareness about the availability of credit, and the greater his access to credit. Similarly, the older the farmer, the more likely he is to have a large household and the greater the probability for him to expand his production for consumptions and to meet financial obligations. Therefore, the need for credit to increase production can not be over emphasized.

The household size is the number of people that are dependent on the farmer. They could be children, wives or relatives. Table1 further indicates that 54 percent of borrowers have between 1 - 10 dependents, while 38 percent of non-borrowers also had between 1-10 dependents, The household size of the farmers will determine his amount of disposable income perannun. It also determines the types of crops to be grown and whether he grows these crops for consumption or for market.

The study further indicated that 42 percent of the borrowers had 11-20 years of farming experience while only 30 percent of their counterpart had such farming experience; in a related study, Osuntogun (1980) revealed that farming experience of a farmer can affect his ability to manage, operate a farm as well as increase familiarity to credit source.

Similarly 38 percent of borrowers had secondary and tertiary education while nonborrowers did not acquire secondary and tertiary education.. An educated farmer will be a customer to institutional credit agencies because he will find it much easier to obtain and fill credit forms than an illiterate farmer. Osugwa (1987) noted that formal education enhances the farmer's entrepreneurial ability; i.e ability to perceive, interpret and respond to new events in the context of innovation, and farmers appreciate the demand of modern farming.

Furthermore 60 percent of borrowers cultivated 2.0 - 2.5 hectares of farm land while only $52 \%$ percent of their counterpart cultivated the same size of land, this might be as a result of borrowers access to loan. Baker and Bhargardy (1983) reported that as the farm size increases, farmers become more specialized and there is need for longer investment and adoption of latest technologies, to those requirements, majority of the farmers would seek for credits.

Result in Table 1also indicated that 16 percent of borrowers made use of hired labour which was not use at all by the non borrowers. This is as a result access to loan by the borrowers which enable them to afford paying for hired labour wages. Osun to Ogun (1980) in his view stated that availability of labour influence farm sizes which certainly would increase production.

The impact of loan utilization by rice farmers refers to how it influences their productivity either negatively or positively. This was achieved through determining the output of borrowers and non-borrowers and comparing them to know if there was a difference. 
TABLE 1: Socio - Economic Characteristics of Respondent

\begin{tabular}{|c|c|c|c|c|}
\hline \multirow[t]{2}{*}{ Characteristics of va } & \multicolumn{2}{|c|}{ Borrowers } & \multicolumn{2}{|c|}{ Non - Borrowers } \\
\hline & Frequency & $\%$ & Frequency & $\%$ \\
\hline $0-29$ & 6 & 12 & 11 & 22 \\
\hline $30-39$ & 26 & 52 & 16 & 32 \\
\hline $40-49$ & 18 & 36 & 23 & 46 \\
\hline \multicolumn{5}{|l|}{ Family Size } \\
\hline $1-10$ & 27 & 54 & 19 & 38 \\
\hline $11-20$ & 22 & 44 & 31 & 62 \\
\hline $21-30$ & 1 & 2 & - & - \\
\hline \multicolumn{5}{|c|}{ Farming Experience (Years) } \\
\hline $1-5$ & 13 & 26 & 10 & 20 \\
\hline $6-10$ & 16 & 32 & 25 & 50 \\
\hline $11-15$ & 12 & 24 & 11 & 22 \\
\hline $16-20$ & 9 & 18 & 4 & 8 \\
\hline \multicolumn{5}{|l|}{ Educational Status } \\
\hline Arabic education & 5 & 10 & 18 & 36 \\
\hline Primary education & 18 & 36 & 19 & 38 \\
\hline Secondary education & 16 & 32 & - & - \\
\hline Tertiary & 3 & 6 & - & - \\
\hline Illiterate & 8 & 16 & 13 & 26 \\
\hline \multicolumn{5}{|l|}{ Farms Size (Hg) } \\
\hline $1-1.5$ & 12 & 24 & 20 & 40 \\
\hline $2.0-2.5$ & 30 & 60 & 26 & 52 \\
\hline $3.0-3.5$ & 8 & 16 & 16 & 8 \\
\hline \multicolumn{5}{|l|}{ Labour Source } \\
\hline Family & 42 & 84 & 50 & 100 \\
\hline Hired & 8 & 16 & - & - \\
\hline
\end{tabular}

Source: Field Survey data, 2008.

Table 2 revealed that borrower had maximum output of 40 bags of rice sold at $\mathrm{N} 40,000.00$ compared to the non-borrowers output of 8 bags sold at $\mathrm{N} 28,800.00$. The minimum output of borrowers was 15 bags sold at $N 52,500.00$ while that of their counter parts was 3 bags

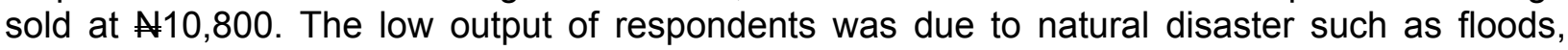
during the farming season. Regardless of the natural disaster, the above result shows that the borrowers had higher yield compared to the non-borrowers, especially since many of the borrowers cultivated large hectare than the non-borrowers, It is expected that the output of the borrowers judging from their position of having larger farm land, higher educational qualifications, access to loans, more years of farming experience and use of hired labour as compared to the non-borrowers. The impact of loan utilization on the farmer's productivity was positive irrespective of the loss due to natural disaster. As some of the respondents confirmed that their output turns out was as a result of the loan they had collected. 
Journal of Agricultural Extension

Vol. 13 (2) December 2009

TABLE 2: Output Level of Borrower and Non-borrowers

\begin{tabular}{|c|c|c|c|c|}
\hline \multirow[b]{2}{*}{ Borrower } & \multicolumn{2}{|c|}{ Maximum } & \multicolumn{2}{|c|}{ Minimum } \\
\hline & Quantity & Price & Quantity & Price \\
\hline & 40 bags & $\$ 140,000$ & 15 bags & A52,500 \\
\hline Non - borrower & 8 bags & $A 28,800$ & 3 bags & A10,800 \\
\hline
\end{tabular}

Source: Field Survey, 2008.

\section{Paired Sample Statistic}

Findings in Table 3 revealed that the mean output of rice farmers who obtained loan was $1,375 \mathrm{~kg}$ with standard deviation of 408.541 and standard error of 57.77 while that of the rice farmers without credit was $275 \mathrm{~kg}$ and with standard deviation of 63.96 and standard 9.04 there is a significant difference in the average output of farmers with credit and those without credit.

TABLE 3: Pair Sample Statistic

\section{Mean Frequency Standard deviation Standard error}

$\begin{array}{lllll}\text { Output with credit } & 1375 & 50 & 408.541 & 57.77 \\ \text { Output without credit } & 275 & 50 & 63.96 & 9.05\end{array}$

Source: Filed survey 2008.

\section{Paired Sample Test}

Result in Table 4 revealed that there is distinct difference between the mean rice output of borrowers and non-borrowers. T-test analysis of difference in their output gave a high mean output of $1,375 \mathrm{~kg}$ for borrowers compared to low mean output of $275 \mathrm{~kg}$ recorded for nonborrowers. The low mean output recorded for non-borrowers was attributed to flood and lack of fund which limits their production. On the other hand, the higher mean output recorded by the borrowers could have arisen from access to credit and large farm lands cultivated by borrowers. Standard deviation was 408.541, standard error being 57.77 , t-cal was 18.44 with degree of freedom at 49. Since t-calculated $>$ t-tabulated, the null hypothesis $\left(H_{\circ}\right)$ is therefore rejected. This implies that there is significant difference in output between the farmers with access to credit and their counterpart. 
TABLE 4: T-test Analysis of Difference in Rice Output of Borrowers and Non-borrowers

\begin{tabular}{lcccccccc}
\hline Groups & number & mean & std dev. & std error & $\mathbf{t}$ & $\mathbf{d f}$ & $\mathbf{p}$ & Remark \\
\hline Borrowers & 50 & 1375 & 408.541 & 57.77 & & & & \\
& & & & & 18.44 & 49 & 0.5 & significant \\
Non borrowers & 50 & 275 & 63.96 & 9.04 & & & & \\
\hline
\end{tabular}

Source: Computed from filed survey data, 2008

\section{CONCLUSION AND POLICY RECOMMENDATIONS}

The study aims at assessing the impact of credit on rice output of rural youth farmers; The result of the study revealed that majority of the respondents are within the age range of 30-49 years while most of the respondents have between 1-10 household sizes. The mean rice output for the borrowers stood at $1,375 \mathrm{~kg}$ while that of non-borrowers was $275 \mathrm{~kg}$. The analysis of T-test shows that there is significant difference between the rice output of borrowers and nonborrowers which implies that the credit have impact on the productivity of the farmers. Based on the findings, the following recommendations were made; Credit institutions should set up supervisory agencies that would monitor farming activities in order to ensure effective and judicious use of such loans. Secondly the process of loans acquisition should be simplified in order to attract and motivate the intended users. Furthermore the farmers should be involved in policy making process, this is because small scale peasant Nigeria farmers are the most effective means of meeting the food need of this country. Finally the farmers on their part should be encouraged to pay back the loan obtained to check the high rate of defaults. 
Journal of Agricultural Extension

Vol. 13 (2) December 2009

\section{REFERENCES}

Adegeye, A.J. and J.S. Dittoh (1985). Essentials of Agricultural Economics. Impact Publishers Nigeria Limited pp150-160.

Awoyemi, O. (1998) Problem of Agriculture in Nigeria. Edited proceeding of Central bank of Nigeria Seminar on Agricultural Credit and finance in Nigeria Lagos.

Baker, C.B. and Bhargargu (1983). "Financing small farmers development in India" Australlia Journal of Agricultural Economics (18), 101-118.

Fabiyi and K.O. Osotimehin (1984). An analysis of the impact of credit on rice production "A case study of Ondo State, Nigeria. Saving and Development Quarterly Review, No. 4 pp $351-360$.

Ilebami, B.C., (1983). The impact of credits on small scale food producing farmers in Akoko south and North local government area of Ondo State. Unpublished M.Sc thesis Department of Agricultural Economic and Rural Sociology A.B.U Zaria 32p.

Osuntagun, A. (1980). Some aspects of farm level credit use in Nigeria Saving and Development Quarterly Review, No. 1.

Osungwa, S.S. (1987). "Institutional Agricultural Credit Strategies for increased food production in Sieera Leone". West African Journal of Agricultural Economics vol.1.

Oyatode, E.T.O. (1981). Financing small farmers. A change of strategy Proceeding, C.B.N Seminar on Agricultural and financing in Nigeria, problem and prospect 132p. 